Journal of Zhejiang University SCIENCE B ISSN 1673-1581 (Print); ISSN 1862-1783 (Online)

www.zju.edu.cn/jzus; www.springerlink.com

E-mail: jzus@zju.edu.cn

\title{
Review:
}

\section{Mechanisms and assessment of water eutrophication*}

\author{
Xiao-e YANG ${ }^{\dagger 1}$, Xiang WU ${ }^{1,2}$, Hu-lin $\mathrm{HAO}^{1}$, Zhen-li $\mathrm{HE}^{1,3}$ \\ $\left({ }^{1}\right.$ MOE Key Laboratory of Polluted Environment Remediation and Ecological Health, Zhejiang University, Hangzhou 310029, China) \\ ('Zhejiang Provincial Key Laboratory of Subtropic Soil and Plant Nutrition, Zhejiang University, Hangzhou 310029, China) \\ $\left({ }^{3}\right.$ Institute of Food and Agricultural Sciences, Indian River Research and Education Center, University of Florida, Fort Pierce, FL 34945, USA) \\ †E-mail: xyang@zju.edu.cn \\ Received Dec. 24, 2007; revision accepted Jan. 28, 2008
}

\begin{abstract}
Water eutrophication has become a worldwide environmental problem in recent years, and understanding the mechanisms of water eutrophication will help for prevention and remediation of water eutrophication. In this paper, recent advances in current status and major mechanisms of water eutrophication, assessment and evaluation criteria, and the influencing factors were reviewed. Water eutrophication in lakes, reservoirs, estuaries and rivers is widespread all over the world and the severity is increasing, especially in the developing countries like China. The assessment of water eutrophication has been advanced from simple individual parameters like total phosphorus, total nitrogen, etc., to comprehensive indexes like total nutrient status index. The major influencing factors on water eutrophication include nutrient enrichment, hydrodynamics, environmental factors such as temperature, salinity, carbon dioxide, element balance, etc., and microbial and biodiversity. The occurrence of water eutrophication is actually a complex function of all the possible influencing factors. The mechanisms of algal blooming are not fully understood and need to be further investigated.
\end{abstract}

Key words: Eutrophication mechanisms, Influencing factors, Nutrient enrichment, Assessment criterion, Water quality doi:10.1631/jzus.B0710626

Document code: A

CLC number: X52

\section{INTRODUCTION}

Water eutrophication is one of the most challenging environmental problems in the world. The increasing severity of water eutrophication has been brought to the attention of both the governments and the public in recent years. The mechanisms of water eutrophication are not fully understood, but excessive nutrient loading into surface water system is considered to be one of the major factors (Fang et al., 2004; Tong et al., 2003). The nutrient level of many lakes and rivers has increased dramatically over the past 50 years in response to increased discharge of domestic wastes and non-point pollution from agricultural practices and urban development (Mainstone and Parr, 2002). For more than 30 years, nutrient enrichment, especially phosphorus $(\mathrm{P})$ and nitrogen $(\mathrm{N})$, has been

\footnotetext{
*Project supported by the Key Project from the Ministry of Education of China (No. 705824), the Project from Science and Technology Bureau of Zhejiang Province (No. 2006C13059), and a grant from the St. Lucie River Water Initiative (SFWMD contract No. OT060162), USA, in part
}

considered as a major threat to the health of coastal marine waters (Andersen et al., 2004). Once a water body is eutrophicated, it will lose its primary functions and subsequently influence sustainable development of economy and society. Therefore, nowadays the solution of water eutrophication and recovery of the multiple functions of the water system have become the key issues for environmental biologists. The main purpose of this paper is to provide a brief review on recent advances on understanding the mechanisms of water eutrophication and progresses in identifying the influence factors inducing water eutrophication.

\section{DEFINITION AND OCCURRENCE OF WATER EUTROPHICATION}

\section{Definition of water eutrophication}

Lakes and estuaries accumulating large amounts of plant nutrients are called "eutrophic" (from the Greek words eu meaning "well" and trophe meaning 
"nourishment"). Eutrophication can be defined as the sum of the effects of the excessive growth of phytoplanktons leading to imbalanced primary and secondary productivity and a faster rate of succession from existence to higher serial stage, as caused by nutrient enrichment through runoffs that carry down overused fertilizers from agroecosystems and/or discharged human waste from settlements (Khan and Ansari, 2005). Water eutrophication can be greatly accelerated by human activities that increase the rate of nutrient input in a water body, due to rapid urbanization, industrialization and intensifying agricultural production. For lake aquatic ecosystems, human activities in the watershed can lead to loss of dominant species and functional groups, high nutrient turnover, low resistance, high porosity of nutrients and sediments, and the loss of productivity (Liu and Qiu, 2007). For example, aquaculture is one of many human activities contributing to the environmental decline of coastal waters and the collapse of fisheries stocks worldwide (Alongi et al., 2003). Because the influence of the human activities, excessive nitrogen, phosphorus and other nutrients are loaded into water bodies like lake, reservoirs, embouchure and bay, which could cause negative ecological consequences on aquatic ecosystem structures, processes and functions, result in the fast growth of algae and other plankton, and deteriorate water quality (Western, 2001). Generally speaking, water eutrophication is caused by the autotrophy algae blooming in water, which composes its bioplasm by sunlight energy and inorganic substances through photosynthesis - the process of eutrophication is described as follows:

$$
\begin{aligned}
& 106 \mathrm{CO}_{2}+16 \mathrm{NO}_{3}^{-}+\mathrm{HPO}_{4}^{2-}+122 \mathrm{H}_{2} \mathrm{O}+18 \mathrm{H}^{+} \\
& \stackrel{\text { Energy+microelement }}{\longrightarrow} \mathrm{C}_{106} \mathrm{H}_{263} \mathrm{O}_{110} \mathrm{~N}_{16} \mathrm{P} \quad \text { (bioplasm } \\
& \text { of algae) }+138 \mathrm{O}_{2} \text {. }
\end{aligned}
$$

According to above equation, it can be concluded that inorganic nitrogen and phosphorus are the major control factors for the propagation of algae, especially phosphorus. The Florida Everglades, a wetland of international importance, has been undergoing a significant shift in its native flora and fauna due to excessive total phosphorus (TP) loadings (an average of 147 ton per annum from 1995 to 2004) and an elevated mean TP concentration $(69 \mu \mathrm{g} / \mathrm{L}$ of TP in 2004) from agricultural runoff and Lake Okeechobee outflow de- spite the use of over 17000 ha of stormwater treatment areas (Richardson et al., 2007).

\section{Assessment of water eutrophication}

Surface water quality guidelines have been improved in recent years. The parameters to assess the ambient surface water quality have been increased. In China, the parameters for assessing environmental quality of surface water have been increased to over 30 (CNEPA, 2002). Five classes of surface water quality have been set up, and some selected parameters for assessing water quality of lakes or reservoirs are shown in Table 1. However, there are no perfect evaluation criteria for assessing water eutrophication. Generally, the physical and chemical evaluation parameters were used to assess water eutrophication, mainly nutrient concentration ( $\mathrm{N}$ and $\mathrm{P}$ ), algal chlorophyll, water transparency and dissolved oxygen. Although there are many different assessment parameters, the concentrations of total nitrogen and phosphorus are the two basic ones. Cheng and $\mathrm{Li}$ (2006) used total nutrient status index (TNI) to assess eutrophication status of lakes. The calculation of total nutrient status index is as follows:

$$
T N I=\sum W_{j} T N I_{j}, W_{j}=r_{i j}^{2} / \sum r_{i j}^{2},
$$

where, TNI is the sum of indexes of all nutrient parameters, $T N I_{j}$ is the TNI of $j$ parameter, $W_{j}$ is the proportion of $j$ parameter in the TNI, and $r_{i j}$ is the relation of chlorophyll a (Chla) to other parameters. The available parameters concerned include total nitrogen (TN), total phosphorus (TP), Chla, dissolved oxygen (DO), chemical oxygen demand by $\mathrm{K}_{2} \mathrm{MnO}_{4}$ oxidation method $\left(\mathrm{COD}_{\mathrm{Mn}}\right)$, biological oxygen demand $\left(\mathrm{BOD}_{5}\right)$, etc., and $\mathrm{TN}, \mathrm{TP}$ and Chla are selected for calculating the TNI (Cheng and Li, 2006). Table 2 shows the burthen values of TN, TP and TNI in various eutrophicated water. It has been shown that the eutrophication or red tide occurs when $\mathrm{N}$ concentration in water reaches $300 \mu \mathrm{g} / \mathrm{L}$ and $\mathrm{P}$ concentration reaches $20 \mu \mathrm{g} / \mathrm{L}$. Richardson et al.(2007) reported that exceeding a surface water mean TP threshold concentration of $15 \mu \mathrm{g} / \mathrm{L}$ causes an ecological imbalance in algal, macrophyte and macroinvertebrate assemblages as well as slough community structure in the Everglades areas. Therefore, it is considered that a threshold zone (12 15 $\mu \mathrm{g} / \mathrm{L})$ of TP may be more realistic and protective for all trophic levels. 
Table 1 The criteria of surface water quality for lakes or reservoir (CNEPA, 2002)

\begin{tabular}{|c|c|c|c|c|c|}
\hline \multirow{2}{*}{ Items } & \multicolumn{5}{|c|}{ Surface water quality classification } \\
\hline & Class I & Class II & Class III & Class IV & Class V \\
\hline Water temperature $\left({ }^{\circ} \mathrm{C}\right)$ & \multicolumn{5}{|c|}{ Maximum week increase $\leq 1$; maximum week decrease $\leq 2$} \\
\hline $\mathrm{pH}$ & \multicolumn{5}{|c|}{$6 \sim 9$} \\
\hline $\mathrm{DO}(\mathrm{mg} / \mathrm{L})$ & Saturation $\geq 90 \%$ & $\geq 6$ & $\geq 5$ & $\geq 3$ & $\geq 2$ \\
\hline $\mathrm{COD}_{\mathrm{Mn}}(\mathrm{mg} / \mathrm{L})$ & $\leq 2$ & $\leq 4$ & $\leq 6$ & $\leq 10$ & $\leq 15$ \\
\hline $\mathrm{COD}_{\mathrm{Cr}}(\mathrm{mg} / \mathrm{L})$ & $\leq 15$ & $\leq 15$ & $\leq 20$ & $\leq 30$ & $\leq 40$ \\
\hline $\mathrm{BOD}_{5}(\mathrm{mg} / \mathrm{L})$ & $\leq 3$ & $\leq 3$ & $\leq 4$ & $\leq 6$ & $\leq 10$ \\
\hline $\mathrm{TN}(\mathrm{mg} / \mathrm{L})$ & $\leq 0.2$ & $\leq 0.5$ & $\leq 1.0$ & $\leq 1.5$ & $\leq 2.0$ \\
\hline $\mathrm{NH}_{3}-\mathrm{N}(\mathrm{mg} / \mathrm{L})$ & $\leq 0.15$ & $\leq 0.5$ & $\leq 1.0$ & $\leq 1.5$ & $\leq 2.0$ \\
\hline $\mathrm{NO}_{2}-\mathrm{N}(\mathrm{mg} / \mathrm{L})$ & $\leq 0.06$ & $\leq 0.1$ & $\leq 0.15$ & $\leq 1.0$ & $\leq 1.0$ \\
\hline $\mathrm{TP}(\mathrm{mg} / \mathrm{L})$ & $\leq 0.01$ & $\leq 0.025$ & $\leq 0.05$ & $\leq 0.1$ & $\leq 0.2$ \\
\hline Chlorophyll a & $\leq 0.001$ & $\leq 0.004$ & $\leq 0.01$ & $\leq 0.03$ & $\leq 0.065$ \\
\hline Transparency (m) & $\geq 15$ & $\geq 4$ & $\geq 2.5$ & $\geq 1.5$ & $\geq 0.5$ \\
\hline Escherichia coli $\left(\mathrm{L}^{-1}\right)$ & $\leq 200$ & $\leq 2000$ & $\leq 10000$ & $\leq 20000$ & $\leq 40000$ \\
\hline
\end{tabular}

DO: dissolved-oxygen; $\mathrm{COD}_{\mathrm{Mn}}$ : Chemical oxygen demand by $\mathrm{K}_{2} \mathrm{MnO}_{4}$ oxidation method; $\mathrm{COD}_{\mathrm{Cr}}$ : Chemical oxygen demand by chromium oxidation method; $\mathrm{BOD}_{5}$ : Biological oxygen demand; TN: Total nitrogen; TP: Total phosphorus

Table 2 The burden values of $\mathbf{N}$ and $P$ in various eutrophicated water

\begin{tabular}{lccccc}
\hline \multicolumn{1}{c}{ Eutrophic status } & $T P(\mu \mathrm{g} / \mathrm{L})$ & $T N(\mu \mathrm{g} / \mathrm{L})$ & Primary productivity & $T N I$ & References \\
\hline Oligotropic water & $5 \sim 10$ & $250 \sim 600$ & $5 \sim 300 \mathrm{mg} \mathrm{C} / \mathrm{m}^{2}$ & $0 \sim 30$ & Likens et al. $(1977)$ \\
Moderately eutrophic & $10 \sim 30$ & $500 \sim 1100$ & $1000 \mathrm{mg} \mathrm{C} /\left(\mathrm{m}^{2} \cdot \mathrm{d}\right)$ & $31 \sim 60$ & Cheng and Li $(2006)$ \\
Eutrophic & $30 \sim 100$ & $1000 \sim 2000$ & - & $61 \sim 100$ & Richardson et al. $(2007)$ \\
Hypereutropic & $>100$ & $>2000$ & - & $>100$ & \\
\hline
\end{tabular}

TN: Total nitrogen; TP: Total phosphorus, TNI: Total nutrient status index

Inglett and Reddy (2006) reported evidences to support the use of stable C (delta C-13) and $\mathrm{N}$ (delta $\mathrm{N}-15$ ) isotopic ratios as indicators for eutrophication and shifts between $\mathrm{N}$ and $\mathrm{P}$ limitation. Lin et al.(2006) compared the stable isotopes from dissolved nutrients and plants and water column nutrient parameters and integration of multiple proxies in a sediment core from Meiliang Bay of Taihu Lake, and found that differences in aquatic plant species and trophic status between East Taihu Bay and Meiliang Bay are indicated by their variations in delta $\mathrm{C}-13$ and delta $\mathrm{N}-15$ of aquatic plants and delta $\mathrm{N}-15$ of $\mathrm{NH}_{4}^{+}-\mathrm{N}$. A significant influence of external nutrient inputs on water quality of Meiliang Bay is reflected in temporal changes in delta $\mathrm{N}-15$ of $\mathrm{NH}_{4}^{+}-\mathrm{N}$ and hydro-environmental parameters. The synchronous change between delta $\mathrm{C}-13$ and delta $\mathrm{N}-15$ values of sedimented organic matter $(\mathrm{OM})$ has been attributed to elevated primary production at the beginning of eutrophication between 1950 and 1990, and then recent inverse correlation between them has been caused by the uptake of $\mathrm{N}-15$-enriched inorganic nitrogen by phytoplankton grown under eutrophication and subsequent $\mathrm{OM}$ decomposition and denitrification in surface sediments, indicating that the lake has suffered from progressive eutrophication since 1990.

More sensitive biological indicators for assessing water eutrophication are needed to further study. Water eutrophication caused a degradation of healthy aquatic ecosystem, so the assessment methods and parameters should reflect the extents of aquatic ecosystem health. A set of ecological indicators including structural, functional and system-level aspects were proposed for a lake ecosystem health assessment, according to the structural, functional and system-level responses of lake ecosystems to chemical stresses including acidification, eutrophication, and copper, oil and pesticide contamination. The structural indicators included phytoplankton cell size and biomass, zooplankton body size and biomass, species diversity, macro- and micro-zooplankton biomass, the zooplankton/phytoplankton ratio, and the macrozooplankton/microzooplankton ratio. The functional indicators encompassed the algal $\mathrm{C}$ assimilation ratio, 
resource use efficiency, community production, gross production/respiration (i.e., $\mathrm{P} / \mathrm{R}$ ) ratio, gross production/standing crop biomass (i.e., $\mathrm{P} / \mathrm{B}$ ) ratio, and standing crop biomass/unit energy flow (i.e., B/E) ratio. The ecosystem-level indicators consisted of ecological buffer capacities, energy, and structural energy. Based on these indicators, a direct measurement method (DMM) and an ecological modeling method (EMM) for lake ecosystem health assessment were developed (Xu et al., 2001). The results of a case study demonstrate that both methods provided similar results which corresponded with the lake's actual trophic state.

\section{Occurrence of water eutrophication}

The investigation from the UNEP (United Nation Environmental Protection) indicates that about $30 \% \sim 40 \%$ of the lakes and reservoirs have been affected more or less by water eutrophication all over the world. Table 3 cites selected samples of water eutrophication occurrence in lake, reservoir, estuary and river in the world. Erie Lake is excessively rich in nutrients (Reutter, 1989), which has resulted in huge blooms of floating blue-green algae and the attached green alga, Cladophora spp. These blooms have rolled onto beaches in large mats resembling green steel wool. Water eutrophication has been reported in USA for Washington Lake (Welch and Crooke, 1987), Okeechobee Lake (Schelske, 1989), City Park Lake (Ruley and Rusch, 2002), etc. In Lugano Lake, between Italy and Switzerland, a faster rate of eutrophication was reported due to excessive discharges from human settlements around the lake, owing to population increase and immigration (Barbieri and Simona, 2001). The majority of Danish lakes are highly eutrophic due to high nutrient input from domestic sources and agricultural activities (Jeppesen et al., 1999). Garg et al.(2002) studied three lakes of Bhopal (Upper Lake, Lower Lake and Mansarovar Lake) in India, to assess the potential fertility of lentic waters and analyze the floral ecology. The highest level of eutrophication was found in Mansarovar

Table 3 Selected samples of water eutrophication occurrence in lake, reservoir, estuary and river in the world

\begin{tabular}{|c|c|c|c|c|}
\hline Water body & $\begin{array}{l}\text { Nutrient }(\mathrm{N}, \mathrm{P}) \\
\text { concentrations }\end{array}$ & $\begin{array}{c}\text { Phytoplankton } \\
\text { biomass }\end{array}$ & History of eutrophication & References \\
\hline Erie Lake, USA & TP: $115 \mu \mathrm{g} / \mathrm{L}$ & $\begin{array}{l}\text { Chlorophyll a: } \\
58 \mu \mathrm{g} / \mathrm{L}\end{array}$ & $\begin{array}{l}\text { Blu-green algae bloom } \\
\text { between } 1965 \text { and } 1979 ; \\
\text { Declined quality from } 1995\end{array}$ & $\begin{array}{l}\text { Reutter, 1989; } \\
\text { Maggie, 2004 }\end{array}$ \\
\hline $\begin{array}{l}\text { Okeechobee Lake, } \\
\text { Florida, USA }\end{array}$ & TP: $50 \sim 100 \mu \mathrm{g} / \mathrm{L}$ & $\begin{array}{l}\mathrm{N} \text { and } \mathrm{P} \text { are limitors } \\
\text { for phytoplankton }\end{array}$ & Eutrophic at present & Schelske, 1989 \\
\hline $\begin{array}{l}\text { City Park Lake, } \\
\text { Louisiana, USA }\end{array}$ & $\begin{array}{l}\text { TN: } 682 \mu \mathrm{g} / \mathrm{L} \\
\text { TP: } 330 \mu \mathrm{g} / \mathrm{L}\end{array}$ & $\begin{array}{l}\text { Chlorophyll a: } \\
35.1 \mu \mathrm{g} / \mathrm{L}\end{array}$ & Eutrophic (2000 2001) & $\begin{array}{l}\text { Ruley and Rusch, } \\
2002\end{array}$ \\
\hline Lugano Lake & TP: $140 \mu \mathrm{g} / \mathrm{L}$ & $\begin{array}{l}\text { Phytoplankton dry } \\
\text { weight: } 7 \sim 16 \mathrm{~g} / \mathrm{m}^{2}\end{array}$ & Strongly eutrophic from 1960s & $\begin{array}{l}\text { Barbieri and Simona, } \\
2001\end{array}$ \\
\hline Danish lakes & $\begin{array}{l}\mathrm{TN}: 2.4 \mathrm{mg} / \mathrm{L} \\
\mathrm{TP}: 0.37 \mathrm{mg} / \mathrm{L}\end{array}$ & $\begin{array}{l}\text { Chlorophyll a: } \\
73 \mu \mathrm{g} / \mathrm{L}\end{array}$ & Highly eutrophic & Jeppesen et al., 1999 \\
\hline $\begin{array}{l}\text { Pamvotis Lake, } \\
\text { Northwest } \\
\text { Greece }\end{array}$ & $\begin{array}{l}\mathrm{TP}: 0.11 \mu \mathrm{g} / \mathrm{L}, \\
\mathrm{NH}_{4}^{+}: 0.25 \mathrm{mg} \mathrm{N} / \mathrm{L} \\
\mathrm{NO}_{3}^{-}: 0.56 \mathrm{mg} \mathrm{N} / \mathrm{L}\end{array}$ & - & $\begin{array}{l}\text { Cultural eutrophication over } \\
\text { the past } 40 \text { years; } \\
\text { Eutrophication at present }\end{array}$ & Romero et al., 2002 \\
\hline $\begin{array}{l}\text { Berg River, South } \\
\text { Africa }\end{array}$ & $\begin{array}{l}\text { TN: } 217 \mathrm{mg} / \mathrm{L} \\
\text { TP: } 70 \mathrm{mg} / \mathrm{L}\end{array}$ & - & Hypertrophic & de Villiers, 2007 \\
\hline $\begin{array}{l}\text { Chivero Lake, } \\
\text { Zimbabwe }\end{array}$ & $\begin{array}{l}\mathrm{TN}: 0.3 \sim 8.4 \mathrm{mg} / \mathrm{L} \\
\mathrm{TP}: 1.01 \sim 5.01 \mathrm{mg} / \mathrm{L}\end{array}$ & $\begin{array}{l}\text { Chlorophyll a: } \\
\quad \text { 18.02 22.48 } \mu \mathrm{g} / \mathrm{L}\end{array}$ & Highly eutrophic since 1980 s & $\begin{array}{l}\text { Nhapi, } 2004 \\
\text { Ndebele and Magadza, } \\
\quad 2006\end{array}$ \\
\hline Taihu Lake, China & $\begin{array}{l}\text { TN: } 2.56 \sim 4.5 \mathrm{mg} / \mathrm{L} \\
\text { TP: } 0.25 \sim 0.35 \mathrm{~g} / \mathrm{L}\end{array}$ & $\begin{array}{l}\text { Algae biomass: } \\
2.7 \sim 6.4 \mathrm{mg} / \mathrm{L}\end{array}$ & $\begin{array}{l}\text { Class I/II in the early } 1960 \mathrm{~s} \text {; } \\
\text { Class IV in the mid-1990s; } \\
\text { Now, inferior Class V }\end{array}$ & $\begin{array}{l}\text { Ye et al., } 2007 \\
\text { Jin } \text { et al., } 2006\end{array}$ \\
\hline $\begin{array}{l}\text { Songhua Lake, } \\
\text { China }\end{array}$ & $\begin{array}{l}\text { TN: } 1.14 \sim 1.98 \mathrm{mg} / \mathrm{L} \\
\text { TP: } 0.038 \sim 0.102 \mathrm{mg} / \mathrm{L}\end{array}$ & $\begin{array}{l}\text { Algae density: } \\
210.84 \times 10^{4} \sim 432.68 \\
\quad \times 10^{4} \text { cell } / \mathrm{L}\end{array}$ & & Wang et al., 2004 \\
\hline $\begin{array}{l}\text { Dianchi Lake, } \\
\text { China }\end{array}$ & $\begin{array}{l}\text { TN: } 2.13 \sim 8.27 \mathrm{mg} / \mathrm{L} \\
\text { TP: } 0.33 \sim 0.59 \mathrm{mg} / \mathrm{L}\end{array}$ & - & $\begin{array}{l}\text { Class III in the early 1970s; } \\
\text { Now, inferior Class V }\end{array}$ & Guo and Sun, 2002 \\
\hline
\end{tabular}


Lake. The nutrient loading into the lake initially promoted the growth of phytoplanktons. Eutrophication constitutes a serious threat to many European lakes (Søndergaard et al., 2007), such as Pamvotis Lake in Northwest Greece (Romero et al., 2002), which has undergone cultural eutrophication over the past 40 years and is currently eutrophic. In South Africa, de Villiers (2007) reported that hypertrophic conditions indicated by TP levels prevail at least episodically at all of the Berg River monitoring stations; additionally, river water phosphate levels show a dramatic increase by a factor of more than 10 over the past 20 years, mainly due to anthropogenic inputs. Chivero Lake, Zimbabwe was reported to be hypertrophic and not sustainable (Nhapi, 2004). Sewage effluent is the major source of nutrients in the lake.

In China, water eutrophication occurred in 67 lakes $(51.2 \%$ of the total lakes). Although the Boyanghu Lake and the Dongtinghu Lake are still mesotrophic at present, Dianchi Lake in Yunnan is possibly the most hypertropic lake in the world. In the early 1970s the water of Dianchi Lake was graded as Class III, now declined to the more inferior Class V (Lu et al., 2005). Taihu Lake, in China, has similar eutrophication issue. It is the third largest freshwater lake in China, located in the Yangtze River delta, one of the more developed areas of eastern China. In recent decades, because of severe pollution, water quality in Taihu Lake degraded from Class I/II in the early 1960s to Class II/III in the early 1980s and then to Class IV by the mid-1990s. At present, $83.5 \%$ of the lake area is eutrophic with an inferior Class V ranking (Liu and Qiu, 2007). The increasingly wider occurrence of excessive algae growth also begins earlier and lasts longer each year in Taihu Lake, and in the summer of 2007 an outbreak of blue algal bloom caused many drinking water treatment plants shut down and created a severe "water crisis event" in Wuxi City. Chaohu Lake is the fifth largest lake in China, located in central Anhui Province, and has a population of 2.3 million and more than 3000 factories in its basin. Since the 1990s, massive and rapid nutrient loading has made it one of the most eutrophic freshwater lakes in China. Jin et al.(2005) reported that eutrophic trend of Taihu Lake, Chaohu Lake and Xuanwu Lake in the region of the middle and lower valleys of Yangtze River was predicated using the ecological stress model. Provided the pollution water treatment rate is $60 \%$ in 2030 , approximately 30 billion ton of polluted water would still be discharged directly into the lakes. Therefore, by 2030, all the urban lakes and most of the medium-sized lakes at the urban-rural fringe areas in China may be eutrophicated or hypertrophicated.

In the region of Yangtze River delta, $80 \%$ of the rivers have been polluted and the water quality cannot meet the standards of drinking water source. The degraded water quality mainly due to eutrophication in this region has resulted in extremely serious problems for drinking water supply. In Zhejiang Province about 36 out of 88 counties are suffering from the short supply of good drinkable water sources. In 2004, water eutrophication and algae blooming even occurred in the Qiantang River, which has the highest water flow velocity in China. High concentration of phosphorus and nitrogen is gradually causing eutrophication.

Water eutrophication in rivers occurs worldwide. During the past several decades, catastrophic losses in seagrass meadows have occurred worldwide, especially in flushed estuaries, coastal embayments and lagoons where nutrient loads are both large and frequent (Burkholder et al., 2007; Ralph et al., 2006). Coastal marine ecosystems of Northern Europe are under pressure from global change (e.g., nutrient enrichment), which threatens these resources (Gowen and Stewart, 2005). There are many statutory obligations and strong political pressures for greatly increased emphasis on the control of nutrients levels in UK rivers because of serious problem of water eutrophication (Mainstone and Parr, 2002). Within Europe, many national and international initiatives have been implemented in order to reduce the inputs and effects of nutrients in waters, e.g., the European Union's Water Framework Directive (Andersen et al., 2004).

\section{Harmfulness of water eutrophication}

Generally speaking, the main harmfulness of water eutrophication is that it can break out the intrinsic equilibrium of the aquatic ecosystem and lead to the damage of the water ecosystem and the gradual degeneration of its functions. As a result, it can affect water quality and make transparency of water become worse than ever. Thus, little sunlight can penetrate water body and photosynthesis of plants under the 
water will be weakened or even stopped. Water eutrophication can also cause the supersaturation or lack of dissolved oxygen in water, which will be dangerous to aquatic animals and cause great death to them. Eutrophic systems tend to accumulate large amounts of organic carbon causing a shift in organic matter biochemical composition (Dell'Anno et al., 2002). Meanwhile, because of water eutrophication, a mass of algae, mainly Cyanophyta and green algae, bloom and form a thick layer of "green scum" on water surface. Algae can release toxins and render the organic matters in water to be decomposed into harmful gases, which will poison the fish and seashell.

The harmfulness of eutrophication also includes causing the shortage supply of drinking water source by degrading water quality. When the blooming algae die, they can produce lots of algae's toxin which is harmful to human health. Cyanobacteria toxins (cyanotoxins) including cytotoxins and biotoxins are responsible for acute lethal, acute, chronic and sub-chronic poisonings of wild/domestic animals and humans. The biotoxins include the neurotoxins; anatoxin-a, anatoxin-a(s) and saxitoxins plus the hepatotoxins; microcystins, nodularins and cylindrospermopsins (Carmichael, 2001). Recent investigation showed that the algae produced toxins, which are the metabolized production of Cyanotoxins, were detected in the Yangtze River, as well as many reservoirs and lakes of Yellow River valleys, apart from Dianchi Lake, Taihu Lake and Chaohu Lakes (Yu and Len, 2004). Besides, increased nitrite concentration in the eutrophic water will be dangerous to human health, too, as products of nitrite nitrification process is a strong carcinogen. Thus, the exacerbation of water eutrophication with the increased severity of algae blooming in surface water system has attracted great attention of both public and private sections.

\section{FACTORS INFLUENCING WATER EUTRO- PHICATION}

Water eutrophication is mainly caused by excessive loading of nutrients into water bodies like $\mathrm{N}$ and P. Excessive nutrients come from both point pollution such as waste water from industry and municipal sewage, and non-point pollution like irrigation water, surface run water containing fertilizer from farmland, etc. Increased nutrient load to water body is now recognized as a major threat to the structure and functions of near shore coastal ecosystems, and severe eutrophication problems associated with harmful algal bloom is a major manifestation. Although related to nutrient enrichment in general, the basic cause of water eutrophication is more connected to an imbalance in the load of nitrogen and phosphorus with respect to silica (Dauvin et al., 2007). At present, excessive TN and TP in water are considered as the only factors inducing water eutrophication, but nutrient enrichment is only the necessary but not the sufficient condition for algal boom. Eutrophication is not likely to occur if both TN and TP in water are low, but eutrophication may not occur in water high in TN and TP if other conditions such as temperature and current speed are not favorable. The influencing factors of water eutrophication include: (1) excessive TN and TP, (2) slow current velocity, (3) adequate temperature and favorable other environmental factors, and (4) microbial activity and biodiversity ( $\mathrm{Li}$ and Liao, 2002). Water eutrophication may occur rapidly when all of these conditions are favorable.

\section{Nutrient enrichment}

There is clear evidence that nutrient loading to lakes, estuaries and coastal oceans has greatly increased through human activities over the past few decades and that this has caused or enhanced many of the symptoms of the aquatic ecosystem transformation known as eutrophication (Bishop et al., 2006). There are different opinions on the relationship of nutrient enrichment to water eutrophication and algal bloom: (1) When P concentration in water is low, it may be the limiting factor for inducing water eutrophication and algal bloom; (2) When P concentration in water increases rapidly, other may become a new limiting factor, such as $\mathrm{pH}$, water depth, temperature, light, wave, wind or other biological factors; (3) The influence of $\mathrm{N}$ and $\mathrm{P}$ still lasts for a longer time because of the high development level of our society (Zhao, 2004).

$\mathrm{N}$ and $\mathrm{P}$ input and enrichment in water are the most primary factors to induce water eutrophication. The "experienced molecular formula" of alga is as " $\mathrm{C}_{106} \mathrm{H}_{263} \mathrm{O}_{110} \mathrm{~N}_{16} \mathrm{P}$ " based on the chemical components of algae. $\mathrm{N}$ and $\mathrm{P}$ are the two elements which account for least proportion in the molecular formula 
of algae, especially $\mathrm{P}$, it is the main limiting factor to control the growth of alga in water (Mainstone and Parr, 2002). It was reported that $80 \%$ lake and reservoir eutrophication is restricted by phosphorus, about $10 \%$ lake and reservoir eutrophication is relative to nitrogen, and the rest $10 \%$ lake and reservoir eutrophication is relative to other factors (Zhao, 2004). In many ecosystems, phytoplankton biomass is correlated with the availability of $\mathrm{N}$ or P (Cloern 2001; Bledsoe et al., 2004). The composition of phytoplankton species is also affected by the concentrations of $\mathrm{N}$ and P (Reynolds, 2006). The ratio of N:P in the water body (referred to as the "Redfield ratio") is an important indicator of which nutrient is limiting eutrophication. If the Redfield ratio is $16: 1, \mathrm{P}$ is most likely the limiting factor for algal growth; lower ratios indicate that $\mathrm{N}$ is of great importance (Redfield et al., 1963; Hodgkiss and Lu, 2004). P has been shown to be the principal limiting nutrient for primary production of phytoplankton in many freshwater environments (Phlips, 2002), while $\mathrm{N}$ is commonly limiting in marine ecosystems (Cloern, 2001). However, there are many exceptions to this general pattern. In some freshwater environments, particularly in the tropics and subtropics, $\mathrm{N}$ has been found to be the primary limiting nutrient for phytoplankton production, due in large part to excessive P load and long growing seasons. For instances, in the Ten Mile Creek of Indian River Lagoon, where TP is $>0.2 \mathrm{mg} / \mathrm{L}$, chlorophyll a and turbidity sharply increased with addition of available $\mathrm{N}(0.2 \sim 6.0 \mathrm{mg} / \mathrm{L})$, but not affected by addition of reactive $\mathrm{P}$ (Lin et al., 2008). The results indicate that available $\mathrm{N}$ is the limiting nutrient for the growth of phytoplankton at water bodies with high P. In phosphate-deficient water bodies or those having reasonably good growth of blue-green algae, which fix enough of the atmospheric nitrogen, phosphorus becomes the limiting element, because a portion of $\mathrm{P}$ is used to counterbalance high nitrate content (Reynolds, 2006). Such circumstances can be seen that no paroxysmal algal boom may break out in heavily eutrophicated water bodies with both high $\mathrm{N}$ and $\mathrm{P}$. Thus, it is the key point to control the concentrations of both $\mathrm{N}$ and $\mathrm{P}$ reasonably for solving the problem of water eutrophication.

The variations in the chemical composition of natural waters are believed to be an important factor in regulating the abundance, composition and geo- graphical and periodic distribution of phytoplankton. It has been considered that the growth of phytoplankton is influenced by dissolved silicate-Si (DSi) concentration in water and its ratio to nitrate. When the DSi:nitrate-N atomic ratio is near $1: 1$, aquatic food webs leading from diatoms which require silicate to fish may be compromised and the frequency or size of harmful or noxious algal blooms may increase. Used together, the DSi:nitrate- $\mathrm{N}$ ratio and nitrate-N concentration are the robust comparative indicators of eutrophication in large rivers (Turner et al., 2003).

\section{Hydrodynamics}

There is no relationship between water disturbance and diatom alga occurrence or its scale, but water disturbing can influence the growth of Pyrrophyta alga because Pyrrophyta alga blooms when it is grown in relatively stable water. Cai et al.(2007) found that when there is no water to dilute, disturbing water itself can influence the process of eutrophication and species succession, which, however, is not related to disturbing water itself but is influenced indirectly by changing light and nutrient status. In shallow water, increased frequency of disturbance could increased the P release from the sediment, especially at high temperature (Cai et al., 2007). This is an instructional point to maintain beneficial alga in water. Also, tide not only can urge alga assembling but can also influence the multiplication of alga bloom through changing the concentration of nutrition in water. Zhu et al.(2007) studied the effects of hydrodynamics on phosphorus concentrations in water of Taihu Lake, a large, shallow and eutrophic lake of China. They found that hydrodynamical disturbance had no significant relationship with water quality at the top layer when significant wave height was smaller than $30 \mathrm{~cm}$, but it significantly increased suspended solids (SS) concentration of the bottom water layer. Concentrations of nutrients showed no positive correlation with SS concentration in the water body. Intensive sediment resuspension may not have occurred when the hydrodynamic stress on sediment was only a little higher than the critical stress for sediment resuspension. A new method for confirming the critical stress for intensive sediment resuspension and nutrient release still needs to be developed. Le Pape and Menesguen (1997) studied hydrodynamic prevention of eutrophication in the 
Brest Bay (France). The Brest Bay is a semi-enclosed coastal ecosystem where primary production is nutrient-limited, even if huge nutrients loading from tributaries are present. The most striking feature of the bay is the semi-diurnal tidal influence, resulting in large water exchange with the continental shelf. A historical study of the available data has shown the steadiness of this ecosystem during the last two decades inspite of increasing eutrophic conditions.

\section{Environmental factors}

A range of factors are related to water eutrophication, but the mechanisms of their influencing algal bloom are not fully understood. In many moderately eutrophicated water bodies, algal bloom occurs in some seasons or some years, when the environmental conditions are favorable. The algal bloom caused by phosphorus inputs also modifies several abiotic factors of the water body. These factors directly govern the growth, diversity and density of the biotic components. The impact of algal bloom on any one or some of these factors indirectly influences the structure and characteristics of the water bodies. The influence of nutrient inputs on some of these factors is discussed as follows:

1. Temperature and salinity are the two important factors to induce alga bloom. Alga bloom always occurs at temperature between $23{ }^{\circ} \mathrm{C}$ and $28{ }^{\circ} \mathrm{C}$, salinity between $23 \%$ and $28 \%$. The variation of temperature and salinity also affect algal bloom, and an important condition for algal bloom is that temperature increases and salinity decreases faster than ever in short time. From the conception of ecology, exquisite change of temperature may cause the subrogation of biological communities, thus leading to algal bloom when other environment conditions are adequate (Wang et al., 1996). Statistical analysis shows that the influence of temperature on algal growth rate is the largest, followed by salinity and their interaction. The process of sporangium pullulating is hypersensitive to temperature. When under adequate temperature, it can bourgeon largely and alga bloom will form very fast. Change of salinity is also influenced by the concentration of nutrition. Research shows that salinity is negatively related with $\mathrm{NO}_{3}^{-}-\mathrm{N}$, and $\mathrm{PO}_{4}^{3-}-\mathrm{P}$, but positively related with $\mathrm{NH}_{4}^{+}-\mathrm{N}$, and however, it is not very related with $\mathrm{NO}_{2}^{-}-\mathrm{N}$. In addition, average temperature in winter is highly relative with the beginning growth time of Gymnodinium, but whether it has universality to all algae still needs to be studied. In the Vistula Lagoon, salinity gradient was determined as an important factor (along with water temperature and predation by young herring) that defined the dynamics of zooplankton abundance and biomass in this estuary (Telesh, 2004).

2. Carbon dioxide level is one of major factors controlling water eutrophication. Cyanophytes are more capable of utilizing low levels of carbon dioxide and become more buoyant at low levels of carbon dioxide and high $\mathrm{pH}$. It keeps them in the upper layers of the water column with abundant sunlight. In addition, some species produce dense mats of vegetation, inhibit the growth of other phytoplankton, and also limit the swimming of zooplankton. These factors together mean that a slow-moving freshwater ecosystem can rapidly become dominated by blue-green algae, displacing not only members of the phytoplankton but some of the animal community as well. The reduction of light reaching the lake floor also inhibits submerged and rooted macrophytes, and sediments become anoxic as large amounts of planktonic biomass are added to them (Kant and Raina, 1990). The fluctuations in free carbon dioxide values correspond directly with the fluctuation in the standing crop of phytoplankton. As the diversity and density of phytoplanktons increase through various months, the amount of free carbon dioxide for photosynthetic activity becomes limiting. The $\mathrm{pH}$ changes in these ponds are governed by the amount of free carbon dioxide, carbon trioxide, and bicarbonate (Kant and Raina, 1990). Inflow nutrient concentration, inflow volume and inflow water temperature show very regular and reasonable impacts on the quality of lake water (Imteaz et al., 2003). Yin (2002) reported that monsoons served as a flushing mechanism in two ways: (1) They reduced seasonal eutrophication by nutrient enrichment in summer, and (2) they prevented long-term (annual) accumulation of organic matter in the sediments due to nutrient enrichment in the region. Because of the monsoon-influenced processes and low phosphorus in the Pearl River estuary, the estuary and adjacent coastal waters of Hong Kong appeared to be more resilient to enrichment of nitrogen.

3. Light plays an important role in the growth, 
diversity and density of aquatic flora. Algal growth has been reported to increase with light intensity, and luminescence of 4000 lux was found most favorable (Shen, 2002). As eutrophication progresses, a decline of submerged macrophytes occurs in many shallow water bodies, probably due to low light intensity caused by algal blooming. It is suggested that the adaptation strategy of Potamogeton maackianus under a certain range of low light stress is to accelerate the elongation of the main and lateral shoots and to increase their density (Ni et al., 1999). The light has been almost completely absorbed by the plankton of the top few meters, so that too little light penetrates to the thermocline and beyond to support photosynthesis. However, there is a rain of corpses into the deep water, whose decomposition requires oxygen. Since the deep water is cut off from the air until fall overturn, an oxygen deficit develops in the deep water, and the bottom mud is reduced. Eutrophication in an estuary is a complex process, and climate change is likely to affect each estuary differently due to interactions with nutrient loading and physical circulation. Hence, it is essential to consider the effects of climate change on the context of individual estuarine function to successfully manage eutrophication (Howarth et al., 2000).

There are other factors like $\mathrm{pH}$ and dissolved oxygen affecting water eutrophication (Khan and Ansari, 2005). The minima and maxima in the concentration of dissolved oxygen are found to be directly related to the maxima and minima of the phytoplankton, The direct relationship between phytoplankton and dissolved oxygen content has been observed by a number of researchers (Khan and Ansari, 2005). $\mathrm{pH}$ is a plant growth limiting factor. The change in $\mathrm{pH}$ is directly related to the availability and absorption of nutrients from solution. Ionization of electrolytes or the valence numbers of different ion species are influenced by changes in $\mathrm{pH}$. An acidic $\mathrm{pH}$ has been reported to promote growth of Spirodelapolyrrhiza at a faster rate, but high $\mathrm{pH}$ values promote the growth of phytoplankton and result in bloom. It must be pointed out that many factors influencing eutrophication are relative and affect each other.

\section{Microbial and biodiversity}

Microbial activity is the inducement factor to alga bloom (Paerl, 1998; Paerl et al., 2003). It can enhance abundant breeding of alga bloom. Nutrient-enhanced microbial production of organic matter, or eutrophication, is frequently accompanied by altered microbial community structure and function (Paerl, 1998). The amount of microbial biomass is positively related to the content of organic matter and the amount of plankton in eutrophicated water. There exists certain intrinsic relationship between the amount of bacteria and the occurrence of eutrophication. The decomposition of organic matter by bacteria activities can produce nutrients and organic substances, which may promote algal bloom breaking out. Of course, it may also produce some toxic substances, which are harmful to other algal species, so that it will selectively enhance the bloom of some algae to become preponderant species and subsequently eutrophication will occur. It may be relative with the decomposing of bacteria biomass, which can promote effective circulation of nutrients when alga bloom and eutrophication occur under lower concentrations of nutrients. Chang et al.(2005) demonstrated that impose of submerged macrophyte in combination of immobilized nitrogen cycling bacteria could effectively reduce chlorophyll a concentration and increase water transparency. Marshland drainage channels (=ditches) in the UK are relicts of a once extensive habitat whose management requires quantitative information on the ecology of marshland organisms. Distribution of these organisms in wetlands worldwide can reflect natural water quality, vegetation and anthropogenic factors (Watson and Ormerod, 2004). Acrophyte-specific richness and abundance increased along an upstream-to-downstream zonation, which was characterized by an increase in mineralization and nutrient level (Thiébaut and Muller, 1998). In hyper-eutrophicated water body, remarkable improvement in water quality and inhibition on algal growth was obtained by introducing nutrient cycling bacteria in proper combination with floating hydrophyte (Chang et al., 2006).

A comparison of aquatic macrophyte diversity of two streams reflected the impact of human-induced perturbations (fish farms, domestic sewage) in such weakly mineralized and poorly buffered waters. Disturbed sites with very high nutrient loading were characterized by low vascular plant richness and by the absence of filamentous algae (Thiébaut and Mul- 
ler, 1998). Vădineanu et al.(1992) studied the phytoplankton and submerged macrophytes in the aquatic ecosystems of the Danube Delta and found that the species changes were linked to accelerated eutrophication of the lakes, with increased phosphorus loading and a reduction in the N/P ratio. Distinct changes were observed in the macrophyte species composition in response to phosphorus enrichment (Vaithiyanathan and Richardson, 1999). Marshes in the unenriched and enriched areas were dominated by Ladiumjamaicense and Typha domingensis, respectively. Open-water areas were characterized by Eleocharis spp., Utricularia spp., Chara zeylanica and Nymphaea odorata in ligotrophic areas and by floating plants and Polygonum spp. in eutrophic areas. A shift in primary producers from eelgrass to macroalgae in response to increased nutrient loading altered the habitat, physicochemical structure and food webs. The nitrogen decreased shoot density and biomass of the eelgrass and promoted a record increase in the algal biomass (Deegan et al., 2002). Enhanced nutrient concentrations and loading have been observed in several coastal areas of the North Sea, resulting in increased production and changes in the species composition of phytoplankton (Colijn et al., 2002). Garg et al.(2002) studied aquatic flora in three lakes of Bhopal (Upper Lake, Lower Lake and Mansarovar Lake) in India and assessed the potential fertility of the lentic water and its aquatic flora. Eutrophication was highest in Mansarovar Lake. The observations of Garg et al.(2002) indicated that different species of phytoplankton could subsist up to a certain nutrient level, beyond which competition between cyanophytes and other algae enhanced and eliminated the sensitive plankton flora.

\section{RESEARCH PERSPECTIVES}

The problem of water eutrophication has become more and more severe worldwide, but the mechanism of its occurrence has not been fully understood. The limited knowledge of water eutrophication processes will add difficulties for the prevention and remediation of water eutrophication. Therefore, more researches should be turned to the mechanisms of water eutrophication under different watershed conditions. For example, the mechanisms of the adsorption and release of the contaminants in sediments should be clarified, which named inner pollution converging in water bodies, especially the absorption and release of $P$ in sediments; the mechanism of the excessive production of algae and Cyanobacteria, especially excessive production of blue-green algae in water should be further studied, which is the key for the prevention of algae and Cyanobacteria growth. Also, the guidelines for estimating eutrophication are still very incomplete. Comprehensive guidelines for assessing eutrophication should be established by considering various factors in combination with the development of economy and society, especially in modern society ecology and health are paid more and more attention in order to avoid adverse influence on the sustainable ecological development and human health to the best of our abilities. In view of the high level of nutrients already polluted into lakes, reservoirs, estuaries, etc., understanding the functions of the factors influencing algal growth and bloom will certainly help controlling algal bloom even at high nutrient burden in surface water bodies.

\section{References}

Alongi, D.M., Chong, V.C., Dixon, P., Sasekumar, A., Tirendi, F., 2003. The influence of fish cage aquaculture on pelagic carbon flow and water chemistry in tidally dominated mangrove estuaries of peninsular Malaysia. Marine Environmental Research, 55(4):313-333. [doi:10.1016/ S0141-1136(02)00276-3]

Andersen, J.H., Conley, D.J., Hedal, S., 2004. Palaeoecology, reference conditions and classification of ecological status: The EU Water Framework Directive in practice. Marine Pollution Bulletin, 49(4):283-290. [doi:10.1016/ j.marpolbul.2004.04.014]

Barbieri, A., Simona, M., 2001. Trophic evolution of Lake Lugano related to external load reduction: Changes in phosphorus and nitrogen as well as oxygen balance and biological parameters. Lakes and Reservoirs Research and Management, 6(1):37-47. [doi:10.1046/j.1440-1770. 2001.00120.x]

Bishop, M.J., Powers, S.P., Porter, H.J., Peterson, C.H., 2006. Benthic biological effects of seasonal hypoxia in a eutrophic estuary predate rapid coastal development. Estuarine Coastal and Shelf Science, 70(3):415-422. [doi:10. 1016/j.ecss.2006.06.031]

Bledsoe, E.L., Phlips, E.J., Jett, C.E., Donnelly, K.A., 2004. The relationships among 336 phytoplankton biomass, nutrient loading and hydrodynamics in an inner-shelf estuary. Ophelia, 58(1):29-47.

Burkholder, J.M., Tomasko, D.A., Touchette, B.W., 2007. Seagrasses and eutrophication. Journal of Experimental Marine Biology and Ecology, 350(1-2):46-72. [doi:10. 
1016/j.jembe.2007.06.024]

Cai, J.B., Ding, X.F., Peng, H.Y., Chang, H.Q., Yang, X.E., 2007. Effects of environmental factors and submerged aquatic plants on phosphorus release from the sediment. Journal of Soil and Water Conservation, 21(2):151-154 (in Chinese).

Carmichael, W.W., 2001. Health effects of toxin-producing Cyanobacteria: "The CyanoHABs". Human and Ecological Risk Assessment, 7(5):1393-1407. [doi:10. 1080/20018091095087]

Chang, H.Q., Yang, X.E., Fang, Y.Y., Pu, P.M., Li, Z.K., 2005. Effects on nutrient of eutrophicated water by Elodea muttallii and immobilized bacteria. Journal of Soil and Water Conservation, 19(3):114-117 (in Chinese).

Chang, H.Q., Yang, X.E., Fang, Y.Y., Pu, P.M., Li, Z.K., Rengel, Z., 2006. In-situ nitrogen removal from the entrophic water by microbial-integrated system. Journal of Zhejiang University SCIENCE B, 7(7):521-531. [doi:10.1631/jzus.2006.B0521]

Cheng, X.Y., Li, S.J., 2006. An analysis on the evolvement processes of lake eutrophication and their characteristics of the typical lakes in the middle and lower reaches of Yangtze River. Chinese Science Bulletin, 51(13): 1603-1613. [doi:10.1007/s11434-006-2005-4]

CNEPA (Environmental Protection Agency of China), 2002. Environmental Quality Standard for Surface Water. GB 3838-2002. http://www.cc.ln.gov.cn/lncj./shownews.asp?

Colijn, F., Hesse, K.J., Ladwig, N., Tillmann, U., Vadstein, O., Olsen, Y., 2002. Effects of the largescale uncontrolled fertilization process along the continental coastal North Sea. Hydrobiologia, 484(1-3):133-148. [doi:10.1023/A: 1021361206529]

Cloern, J.E., 2001. Our evolving conceptual modle of the coastal eutrophication 350 problem. Marine Ecology Progress Series, 210:223-253. [doi:10.3354/meps210223]

Dauvin, J.C., Ruellet, T., Desroy, N., Janson, A.L., 2007. The ecological quality status of the Bay of Seine and the Seine estuary: Use of biotic indices. Marine Pollution Bulletin, 55(1-6):241-257. [doi:10.1016/j.marpolbul.2006.04.010]

de Villiers, S., 2007. The deteriorating nutrient status of the Berg River, South Africa. Water SA, 33(5):659-664.

Deegan, L.A., Wright, A., Ayvazian, S.G., Finn, J.T., Golden, H., Merson, R.R., Harrison, J., 2002. Nitrogen loading alters seagrass ecosystem structure and support of higher tropic levels. Aquatic Conservation Marine and Freshwater Ecosystems, 12(2):193-212. [doi:10.1002/aqc.490]

Dell'Anno, A., Mei, M.L., Pusceddu, A., Danovaro, R., 2002. Assessing the trophic state and eutrophication of coastal marine systems: A new approach based on the biochemical composition of sediment organic matter. Marine Pollution Bulletin, 44(7):611-622. [doi:10.1016/S0025326X(01)00302-2]

Fang, Y.Y., Yang, X.E., Pu, P.M., Chang, H.Q., Ding, X.F., 2004. Water eutrophiocation in Li-Yang Reservoir and its ecological remediation countermeasures. Journal of Soil and Water Conservation, 18(6): 183-186 (in Chinese).

Garg, J., Garg, H.K., Garg, J., 2002. Nutrient loading and its consequences in a lake ecosystem. Tropical Ecology, 43(2):355-358.

Gowen, T.R.J., Stewart, B.M., 2005. The Irish Sea: Nutrient status and phytoplankton. Journal of Sea Research, 54(1):36-50. [doi:10.1016/j.seares.2005.02.003]

Guo, H.C., Sun, Y.F., 2002. Characteristic analysis and control strategies for the eutrophicated problem of the Lake Dianchi. Progress in Geography, 21(5):500-506 (in Chinese).

Hodgkiss, I.J., Lu, S.H., 2004. The effects of nutrients and their ratios on phytoplankton aboundance in Junk Bay, Hong Kong. Hydrobiologia, 512(1-3):215-229. [doi:10. 1023/B:HYDR.0000020330.37366.e5]

Howarth, R.W., Swaney, D.P., Butler, T.J., Marino, R., 2000. Climatic control on eutrophication of the Hudson River estuary. Ecosystems, 3(2):210-215. [doi:10.1007/s10021 0000020]

Imteaz, M.A., Asaeda, T., Lockington, D.A., 2003. Modelling the effects of inflow parameters on lake water quality. Environmental Modeling and Assessment, 8(2):63-70. [doi:10.1023/A:1023905532180]

Inglett, P.W., Reddy, K.R., 2006. Investigating the use of macrophyte stable $\mathrm{C}$ and $\mathrm{N}$ isotopic ratios as indicators of wetland eutrophication: Patterns in the P-affected Everglades. Limnology and Oceangraohy, 51(5):2380-2387.

Jeppesen, E., Søndergaard, M., Kronvang, B., Jensen, J.P., Svendsen, L.M., Lauridsen, T.L., 1999. Lake and catchment management in Denmark. Hydrobiologia, 395-396: 419-432. [doi:10.1023/A:1017071602549]

Jin, X.C., Xu, Q.J., Huang, C.Z., 2005. Current status and future tendency of lake eutrophication in China. Science in China Series C-Life Science, 48((Suppl.)):948-954.

Jin, X.C., Wang, S.R., Pang, Y., Wu, F.C., 2006. Phosphorus fractions and the effect of $\mathrm{pH}$ on the phosphorusrelease of the sediments from different trophic areas in Taihu Lake, China. Environmental Pollution, 139(2):288-295. [doi:10. 1016/j.envpol.2005.05.010]

Kant, S., Raina, A.K., 1990. Limnological studies of two ponds in Jammu. II. Physico-chemical parameters. Journal of Environmental Biology, 11(2):137-144.

Khan, F.A., Ansari, A.A., 2005. Eutrophication: An ecological vision. The Botanical Review, 71(4):449-482. [doi:10. 1663/0006-8101(2005)071[0449:EAEV]2.0.CO;2]

Le Pape, O., Menesguen, A., 1997. Hydrodynamic prevention of eutrophication in the Bay of Brest (France), a modelling approach. Journal of Marine Systems, 12(1-4): 171-186. [doi:10.1016/S0924-7963(96)00096-6]

Li, J.X., Liao, W.G., 2002. Discussion on the synthetic adjustive guidelines for the prevention and cure of eutrophication. Protection of Water Resource, 2(5):4-5.

Likens, G.E., Bormann, F.H., Pierce, R.S., Eaton, J.S., Johnson, N.M., 1977. Biogeochemistry of a Forested Ecosystem. Springer-Verlag, New York.

Lin, L., Wu, J.L., Wang, S.M., 2006. Evidence from isotopic geochemistry as an indicator of eutrophication of Meiliang Bay in Lake Taihu, China. Science in China Series D-Earth Sciences, 49(s1):62-71. [doi:10.1007/s11430- 
006-8106-8]

Lin, Y.J., He, Z.L., Yang, Y.G., Stoffella, P.J., Philips, E.J., Powella, C.A., 2008. Nitrogen versus phosphorus limitation of phytoplankton growth in Ten Mile Creek, Florida, USA. Hydrobiologia, in press.

Liu, W., Qiu, R.L., 2007. Water eutrophication in China and the combating strategies. Journal of Chemical Technology and Biotechnology, 82(9):781-786. [doi:10.1002/ jctb.1755]

Lu, J.J., Yang, H., Gao, L., Yu, T.Y., 2005. Spatial variation of $\mathrm{P}$ and $\mathrm{N}$ in water and sediments of Dianchi Lake, China. Pedosphere, 15(1):78-83.

Maggie, B.M., 2004. Total Maximum Daily Load Effectiveness Monitoring Study: Lakes Erie and Campbell. Quality Assurance Project Plan, No. 04-03-206.

Mainstone, C.P., Parr, W., 2002. Phosphorus in rivers-ecology and management. The Science of the Total Environment, 282-283(1-3):25-47. [doi:10.1016/S0048-9697(01)00937-8]

Ndebele, M.R., Magadza, C.H.D., 2006. The occurrence of microcystin-LR in Lake Chivero, Zimbabwe. Lakes and Reservoirs Research and Management, 11(1):57-62. [doi:10.1111/j.1440-1770.2006.00287.x]

Nhapi, I., 2004. Options for Wastewater Management in Harare, Zimbabwe. Ph.D Thesis, Wageningen University, Wageningen, the Netherlands.

Ni, L.Y., Wang, D.M., Xie, P., 1999. Experimental Studies on the Growth of Potamogeton macckianus A. under Low-Light Stress in Highly Eutrophic Water. Acta Hydrobiologica Sinica, 23:53-58.

Paerl, H.W., 1998. Structure and function of anthropogenically altered microbial communities in coastal waters. Current Opinion in Microbiology, 1(3):296-302. [doi:10.1016/ S1369-5274(98)80033-7]

Paerl, H.W., Dyble, J., Moisander, P.H., Noble, R.T., Piehler M.F., Pinckney, J.L., Steppe, T.F., Twomey, L., Valdes, L.M., 2003. Microbial indicators of aquatic ecosystem change: current applications to eutrophication studies. FEMS Microbiology Ecology, 46(3):233-246. [doi:10. 1016/S0168-6496(03)00200-9]

Phlips, E.J., 2002. Algae and Eutrophication. In: Bitton, G. (Ed.), Encyclopedia of Environmental Microbiology. John Wiley and Sons, New York.

Ralph, P.J., Tomasko, D., Moore, K., Seddon, S., Macinnis-Ng, C.M.O., 2006. Human Impacts on Seagrasses: Eutrophication, Sedimentation, and Contamination. In: Larkum, A.W.D., Orth, R.J., Duarte, C.M. (Eds.), Seagrasses: Biology, Ecology and Conservation. Springer, the Netherlands, p.567-593.

Redfield, A.C., Ketchum, B.H., Richards, F.A., 1963. The Influence of Organisms on the Composition of Seawater. In: Hill, M.N. (Ed.), The Sea. Volume 2. Wiley-Interscience, New York, p.26-77.

Reutter, J.M., 1989. Lake Erie: Phosphorus and Eutrophication. Fact Sheet 015. Ohio Sea Grant College Program, Columbus.

Reynolds, C., 2006. Ecology of Phytoplankton. Cambridge University Press, Cambridge, p.535.
Richardson, C.J., King, R.S., Qian, S.S., Vaithiyanathan, P., Qualls, R.G., Stow, C.A., 2007. Estimating ecological thresholds for phosphorus in the Everglades. Environmental Science and Technology, 41(23):8084-8091. [doi:10.1021/es062624w]

Romero, J.R., Kagalou, I., Imberger, J., Hela, D., Kotti, M., Bartzokas, A., Albanis, T., Evmirides, N., Karkabounas, S., Papagiannis, J., Bithava. A., 2002. Seasonal water quality of shallow and eutrophic Lake Pamvotis, Greece: Implications for restoration. Hydrobiologia, 474(1-3): 91-105. [doi:10.1023/A:1016569124312]

Ruley, J.E., Rusch, K.A., 2002. An assessment of long-term post-restoration water quality trends in a shallow, subtropical, urban hypereutrophic lake. Ecological Engineering, 19(4):265-280. [doi:10.1016/S0925-8574(02) 00096-4]

Schelske, P.C., 1989. Assessment of nutrient effects and nutrient limitation in Lake Okeechobee. Journal of the American Water Resources Association, 25(6):1119-1130. [doi:10.1111/j.1752-1688.1989.tb01325.x]

Shen, D.S., 2002. Study on limiting factors of water eutrophication of the network of rivers in plain. Journal of Zhejiang University (Agriculture and Life Sciences), 28(4):94-97 (in Chinese).

Søndergaard, M., Jeppesen, E., Lauridsen, T.L., Skov, C., van Nes, E.H., Roijackers, R., Lammens, E., Portielje, R., 2007. Lake restoration: Successes, failures and long-term effects. Journal of Applied Ecology, 44(6):1095-1105. [doi:10.1111/j.1365-2664.2007.01363.x]

Telesh, I.V., 2004. Plankton of the baltic estuarine ecosystems with emphasis on Neva Estuary: A review of present knowledge and research perspectives. Marine Pollution Bulletin, 49(3):206-219. [doi:10.1016/j.marpolbul.2004. 02.009]

Thiébaut, G., Muller, S., 1998. The impact of eutrophication on aquatic macrophyte diversity in weakly mineralized streams in the Northern Vosges mountains (NE France). Biodiversity and Conservation, 7(8):1051-1068. [doi:10. 1023/A:1008809131487]

Tong, C.H., Yang, X.E., Pu, P.M., 2003. Degradation of aquatic ecosystem in the catchment of Mu-Ge Lake and its Remediation countermeasures. Journal of Soil and Water Conservation, 17(1):72-88 (in Chinese).

Turner, R.E., Rabalais, N.N., Justic, D., Dortch, Q., 2003. Global patterns of dissolved N, P and $\mathrm{Si}$ in large rivers. Biogeochemistry, 64(3):297-317. [doi:10.1023/A:102496 0007569]

Vădineanu, A., Cristofor, S., Ignat, C., 1992. Phytoplankton and submerged macrophytes in the aquatic ecosystems of the Danube Delta during the last decade. Hydrobiologia, 243-244(1):141-146. [doi:10.1007/BF00007029]

Vaithiyanathan, P., Richardson, C.J., 1999. Macrophyte species changes in the Everglades: Examination along a eutrophication gradient. Journal of Environmental Quality, 28(4):1347-1358.

Wang, X., Lu, X.G., Zhang, X.L., Zhang, Z.Q., 2004. Eutrophication aspects and effective factors analysis in 
Songhua Lake. Wetland Science, 2(4):273-278 (in Chinese).

Wang, Z.F., Zhang, Q., Lu, Y., Lv, H.Y., 1996. The effects of nutrients and trace metals on the growth of the red tide organism Prorocentrum micans. Donghai Marine Sciences, 14(3):33-38.

Watson, A.M., Ormerod, S.J., 2004. The distribution of three uncommon freshwater gastropods in the drainage ditches of British grazing marshes. Aquatic Conservation, 118(3): 455-466.

Welch, F.B., Crooke, G.D., 1987. Lakes. In: Jordan, W.R., Aber, J.D., Gilpin, M.E. (Eds.), Restoration Ecology: A Synthetic Approach to Ecological Research. Cambridge Univ. Press, Cambridge, p.109-129.

Western, D., 2001. Human-modified ecosystems and future evolution. Proceedings of the National Academy of Sciences of the United States of America, 98(10):5458-5465. [doi:10.1073/pnas.101093598]

Xu, F.L., Tao, S., Dawson, R.W., Li, P.G., Cao, J., 2001. Lake ecosystem health assessment: Indicators and methods. Water Research, 35(13):3157-3167. [doi:10.1016/S00431354(01)00040-9]
Ye, C., Xu, Q.J., Kong, H.N., Shen, Z.M., Yan, C.Z., 2007. Eutrophication conditions and ecological status in typical bays of Lake Taihu in China. Environmental Monitoring and Assessment, 135(1-3):217-225. [doi:10.1007/s10661007-9644-z]

Yin, K., 2002. Monsoonal influence on seasonal variations in nutrients and phytoplankton biomass in coastal waters of Hong Kong in the vicinity of the Pearl River estuary. Marine Ecology Progress Series, 245:111-122. [doi:10. 3354/meps245111]

Yu, H.M., Len, Y., 2004. Elementary discussion on the harm of blue alga and its prevention and cure. Beijing Aquatic Product, 1(5):29-30.

Zhao, S.C., 2004. Mechanisms of Lake Eutrophication and technologies for controlling in China. Advance in Earth Sciences, 19(1):138-140.

Zhu, G.W., Qin, B.Q., Gao, G., Zhang, L., Luo, L.C., Zhang, Y.L., 2007. Effects of hydrodynamics on phosphorus concentrations in water of Lake Taihu, a large, shallow, eutrophic lake of China. Hydrobiologia, 581(1):53-61. [doi:10.1007/s10750-006-0519-z] 